\title{
EXTENDED-SPECTRUM $\beta$-LACTAMASES IN KLEBSIELLA SPP AND ESCHERICHIA COLI OBTAINED IN A BRAZILIAN TEACHING HOSPITAL: DETECTION, PREVALENCE AND MOLECULAR TYPING
}

\author{
Ana Lúcia Peixoto de Freitas ${ }^{2,3}$; Denise Pires Machado ${ }^{1}$; Fabiana da Silva Correa Soares ${ }^{1}$; Afonso Luís Barth ${ }^{1,2 *}$ \\ ${ }^{1}$ Unidade de Pesquisa Biomédica do Hospital de Clínicas de Porto Alegre, Porto Alegre, RS, Brasil. ${ }^{2}$ Universidade Federal do Rio \\ Grande do Sul, Porto Alegre, RS, Brasil. ${ }^{3}$ Universidade Católica de Pelotas, Pelotas, RS, Brasil.
}

This paper corresponds to an "extended abstract" selected for oral presentation in the $22^{\text {nd }}$ Brazilian Congress of Microbiology, held in Florianópolis, SC, Brazil, in November 17-20, 2003

\begin{abstract}
His study was performed to compare the methods of detection and to estimate the prevalence of extendedspectrum $\beta$-lactamases (ESBL) among Klebsiella spp and E. coli in a university hospital in southern Brazil. We also used a molecular typing method to evaluate the genetic correlation between isolates of ESBL K. pneumoniae. Production of ESBL was investigated in 95 clinical isolates of Klebsiella spp and Escherichia coli from Hospital de Clínicas de Porto Alegre, using Kirby-Bauer zone diameter (KB), double-disk diffusion (DD), breakpoint for ceftazidime (MIC CAZ), increased zone diameter with clavulanate (CAZ/CAC) and ratio of ceftazidime MIC/ceftazidime-clavulanate MIC (MIC CAZ/CAC). Molecular typing was performed by DNA macrorestriction analysis followed by pulsed-field gel electrophoresis. The KB method displayed the highest rates of ESBL (up to $70 \%$ of Klebsiella and $59 \%$ of E. coli), contrasting with all the other methods $(\mathrm{p}<0.05$ ). The confirmatory methods (DD, MIC CAZ, CAZ/CAC and MIC CAZ/CAC) showed a range of ESBL production from 8 to $13 \%$ for $E$. coli and from 33 to $40 \%$ for Klebsiella species. Therefore, the KB method was useful only as a screening method as it provided several false positive results. Molecular typing of 17 ESBL K. pneumoniae indicated that the isolates had no clonal relation. We found a good correlation among the confirmatory methods for ESBL detection although the methods which evaluate inhibition of the $\beta$-lactamase by clavulanate appeared to be more specific. The high prevalence of ESBL Klebsiella in our hospital is probably due to individual selection of resistant strains rather than the transmission of a common strain.
\end{abstract}

Key words: ESBL, Klebsiella, resistance, molecular typing.

\section{INTRODUCTION}

One of the most prevalent mechanisms of bacterial resistance among Gram-negative bacteria is the production of $\beta$-lactamases. These enzymes comprise a family with high diversity and many schemes for their classification have been proposed (2). Extended-spectrum $\beta$-lactamases (ESBLs) are a group of clinically very important $\beta$-lactamases because they are able to hydrolyze the extended-spectrum cephalosporins (ceftazidime, cefotaxime, ceftriaxone) and monobactans (aztreonam). ESBLs are included in the $2^{\text {nd }}$ group of Bush classification (2) and originally have derived from TEM and SHV enzymes although other classes of ESBL have been described recently (1). Interestingly, the mutations that expand the spectrum of these $\beta$-lactamases usually increase their sensitivity to $\beta$-lactamase inhibitors (clavulanate and sulbactam) $(8,27)$.

*Corresponding author. Mailing address: Unidade de Pesquisa Biomédica, Hospital de Clínicas de Porto Alegre. Rua Ramiro Barcelos 2350. 90.035-003, Porto Alegre, RS, Brasil. Tel.: (+5551) 3316-8607. Fax: (+5551) 3316-8607. E-mail: albarth@hcpa.ufrgs.br 
The prevalence of ESBL varies according to different regions or to different hospitals $(6,26)$. Piddock et al. (24) studied more than 3,000 Enterobacteriaceae from 43 British hospitals, and found that only $1 \%$ of isolates produced ESBL. On the other hand, Lyon et al. (16) found an increase of overall resistance and specifically in ESBL production between 1990 and 1995 in isolates from blood culture in Hong Kong, and emphasize the importance to use appropriate screening methods in order to detect these enzymes since routine diffusion tests might give false negative results. Livermore and Yuan (14), found that 23\% of Klebsiella species isolated from intensive treatment units of 35 European hospitals were EBSL producers. They also described that $33 \%$ of ESBL isolates were reported as susceptible to third generation cephalosporins and monobactams, and this pose as a problem, since treatment of ESBL producers with those agents were associated with failure $(2,9)$. In Brazil there is scarce data about ESBL production in Gram-negative bacteria. In a study using nosocomial isolates, Gales et al. (7) found that 39\% of K. pneumoniae isolated from São Paulo were ESBL producers.

Members of Enterobacteriaceae producing ESBL constitute a serious threat to current $\beta$-lactam therapy, because the in vitro detection of ESBL expression has proved to be troublesome and there is no consensus about the best method to detect ESBL. Practical methods such as double-disk test $(5,16)$, E-test double strip $(3,29)$ and the modified breakpoints for standard susceptibility tests $(22,24)$ have been used by many studies.

Another important aspect is the epidemiological aspect of ESBL producers. Although Cotton et al. (4) had described an outbreak due to horizontal transmission between patients, ESBL can also arise from selection in individual microbiota. The use of cephalosporins, mainly ceftazidime, has been indicated as one of the major risk factors for acquisition of $\operatorname{ESBL}(7,18,21,25)$. Lucet et al. (15) pointed other risk factors for ESBL acquisition which are associated with the severity of illness of patient requiring long stay in intensive care units and presence of catheters.

This study was performed to compare the methods of detection and to estimate the prevalence of ESBL Klebsiella spp and E. coli in a university hospital in southern Brazil (HCPA). In addition we also used DNA macrorestriction analysis by PFGE to evaluate the genetic correlation between isolates of ESBL $K$. pneumoniae.

\section{MATERIALSAND METHODS}

Isolates of E coli and Klebsiella spp were suspended in Mueller-Hinton broth (Oxoid, Basingstoke) to an optical density equal to 0.5 MacFarland standard and this suspension was used to inoculate Mueller-Hinton agar (Oxoid, Basingstoke) plates. The following methods were performed to detect ESBL production: a) Kirby-Bauer zone diameter $(\mathrm{KB})$ : isolates with inhibition zones of $\leq 22 \mathrm{~mm}$ to ceftazidime (CAZ) and/or $\leq 25 \mathrm{~mm}$ to ceftriaxone (CRO) and/or $\leq 27 \mathrm{~mm}$ to aztreonam (ATM) 30 $\mu \mathrm{g}$ disks (Oxoid, Basingstoke) on disk diffusion method were considered as suspicious for ESBL producers (19).

b) Double-disk diffusion (DD): individual disks containing 30 $\mu \mathrm{g}$ of CAZ, CRO and ATM (Oxoid, Basingstoke) were placed onto the plate in a distance of $1.5 \mathrm{~cm}$ (edge to edge) from an amoxicillin/clavulanic acid disk (20/10 $\mu \mathrm{g})$. An enhanced zone of inhibition between any one of the $\beta$-lactam disks and the disk containing clavulanic acid was interpreted as a positive result.

c) Ratio of ceftazidime MIC/ceftazidime-clavulanic acid MIC (MIC CAZ/CAC): this method was performed using an Etest ESBL strip (AB Biodisk, Solna) carrying two gradients: on the one end ceftazidime ( 0.5 to $32 \mu \mathrm{g} / \mathrm{mL})$, and on the opposite end ceftazidime $(0.125$ to $8 \mu \mathrm{g} / \mathrm{mL})$ plus clavulanic acid in a fixed concentration $(4 \mu \mathrm{g} / \mathrm{mL})$. We considered a ratio of MIC CAZ / MIC CAC equal or greater than 8 as presumptive for ESBL production as proposed by the E-test ESBL strip manufacturer and some studies (29).

d) Breakpoint to ceftazidime (MIC CAZ): this procedure used the result of the E-test strip as above and considered a MIC $\geq 2 \mu \mathrm{g} / \mathrm{mL}$ for ceftazidime as an indication of ESBL production (19).

e) Increased zone diameter with clavulanic acid (CAZ/CAC): a $\geq 5 \mathrm{~mm}$ increase in zone diameter for ceftazidime disk $(30 \mu \mathrm{g})$ added of clavulanic acid $(10 \mathrm{mg})$ compared with a ceftazidime disk (Oxoid, Basingstoke) alone indicated ESBL (20).

The results of methods were compared by the Fisher's Exact Test.

DNA Macrorestriction analyses of Klebsiella pneumoniae was performed using DNA digestion followed by pulsed-field gel electrophoresis as stated (10). Briefly, the bacteria was embedded in agarose (Gibco BRL, Grand Island) blocks, transferred to a lysis buffer containing proteinase K (Sigma, St. Louis) for $12 \mathrm{~h}$, and digested with restriction endonuclease SpeI (Gibco BRL). Electrophoresis was carried out in a CHEF DR II apparatus (Bio-Rad, Richmond). The gels were run for $23 \mathrm{~h}$, with switch time of 5 to $25 \mathrm{~s}$. Lambda ladder (48.5 Kb, Sigma) was used as molecular weight marker. Fragments were stained with ethidium bromide (Sigma) and photographed. Visual comparisons were made and the criteria of Tenover et al. (28) was used to establish the relationship among the isolates.

\section{RESULTS}

A total of 95 clinical isolates of E. coli (39 isolates) and Klebsiella spp (47 K. pneumoniae and $9 \mathrm{~K}$ oxytoca) recovered from 94 patients hospitalized in HCPA during a five months period (June to October, 1998) were used in this study. Overall, 20 samples 
were obtained from surgical wounds, 14 from sputum, 13 from blood and the remain from other sites (body fluids and catheters). We were not able to interpret the results of MIC CAZ/CAC for two isolates of $K$. pneumoniae because their MIC for ceftazidime and ceftazidime plus clavulanic acid was above the maximum limit of the strip. These isolates were excluded from the general comparison between methods. According to the NCCLS breakpoints for CAZ, CRO and ATM by the disk-diffusion method (KB) the number of ESBL producers was very high among our isolates: up to $70 \%$ for Klebsiella sp and $59 \%$ for E. coli. Many isolates positive for ESBL by this method were not classified as positive by none of the other methods used in this study as one could expect for a typical screening method.

The confirmatory methods (DD, MIC CAZ and MIC CAZ/ CAC) showed a range of ESBL production similar, from 8 to $13 \%$ for E. coli and from 33 to $40 \%$ for Klebsiella species (Table 1). The efficiency of screening for ESBL-producing isolates according to NCCLS (KB method) with disks of CAZ, CRO and ATM was evaluated for isolates of $K$. pneumoniae according to the other methods. In general, non-resistant isolates were not ESBL producers with the exception of three isolates which were positive for ESBL according to the other methods and susceptible to ceftazidime. It has to be mentioned that one of these isolates was positive only in the DD method. Considering ESBL production in Klebsiella species by methods which evaluate inhibition of the $\beta$-lactamase enzyme by clavulanic acid (doubledisk method and MIC CAZ/CAC method) one will observe very similar results: 19 positive isolates in DD method and 18 isolates in MIC CAZ/CAC (Table 1). Detection of ESBL production in Klebsiella by DD and MIC CAZ indicated that 19 and 22 isolates respectively were ESBL positive (not statistically significant, $\mathrm{p}=0.6919$ ). The number of isolates positive by MIC CAZ/CAC and MIC CAZ were also very similar $(\mathrm{p}=0.847)$ (Table 1$)$.

The occurrence of ESBL in E. coli was not identical whether the DD and MIC CAZ/CAC methods were compared (Table 1).

Table 1. Positive results of methods for ESBL production in E. coli and Klebsiella spp.

\begin{tabular}{|c|c|c|c|c|c|}
\hline $\mathrm{CAZ}^{\mathrm{d}}$ & $\begin{array}{l}\text { No. of } \\
\text { isolates }\end{array}$ & $\mathrm{KB}^{\mathrm{a}}$ & $\mathrm{D}^{\mathrm{b}}$ & $\begin{array}{c}\text { MIC } \\
\text { CAZ/CAC }^{c}\end{array}$ & MIC \\
\hline & 5 & 3 & 1 & $\begin{array}{c}18 \\
(33 \%)\end{array}$ & $\begin{array}{c}22 \\
(40 \%)\end{array}$ \\
\hline ae & 45 & $\begin{array}{c}31 \\
(69 \%)\end{array}$ & $\begin{array}{c}17 \\
(38 \%)\end{array}$ & $\begin{array}{c}16 \\
(36 \%)\end{array}$ & $\begin{array}{c}20 \\
(44 \%)\end{array}$ \\
\hline K. c & 9 & $\begin{array}{c}7 \\
(78 \%)\end{array}$ & $\begin{array}{c}2 \\
(22 \%)\end{array}$ & $\begin{array}{c}2 \\
(22 \%)\end{array}$ & $(22 \%$ \\
\hline E. coli & 39 & $\begin{array}{c}23 \\
(59 \%)\end{array}$ & $\begin{array}{c}5 \\
(13 \%)\end{array}$ & $\begin{array}{c}3 \\
(8 \%)\end{array}$ & $(13 \%$ \\
\hline
\end{tabular}

${ }^{\mathrm{a}}$ Kirby-Bauer disk diffusion; ${ }^{\mathrm{b}}$ Double-disk diffusion; ${ }^{\mathrm{c}}$ Ratio of ceftazidime MIC/ceftazidime-clavulanic acid MIC; ${ }^{\mathrm{d}}$ Breakpoint to ceftazidime.
Two isolates were positive by DD method and negative according to MIC CAZ/CAC. It is of importance to notice that these isolates displayed a difference between MICs of ceftazidime with and without clavulanic acid although this difference did not reach the cutoff ratio. Therefore, the isolates were not completely indifferent to the presence of the $\beta$-lactamase inhibitor.

Since January 1999 the NCCLS proposed a confirmatory test (CAZ/CAC) based on the measurement of the diameter of inhibition. We were able to apply the CAZ/CAC method to 80 isolates (39 K. pneumoniae, $8 \mathrm{~K}$. oxytoca and $31 \mathrm{E}$. coli) and we found that $37 \%$ of $K$. pneumoniae, $25 \%$ of $K$. oxytoca and $16 \%$ of $E$. coli were positive with the confirmatory method.

Considering the high prevalence of $K$. pneumoniae ESBL in HCPA a genetic analysis by DNA macrorestriction followed by PFGE was performed in 17 isolates. Two isolates were obtained from the same patient during an interval of four days but all the other isolates were obtained from different patients. Nine of these isolates were recovered within a period of 25 days. Persistent degradation of DNA occurred in one sample. We were able to identify a great variety of profiles as none of the ESBL $K$. pneumoniae displayed the same pattern of macrorestriction (Fig. 1) with the exception of the isolates obtained from the same patient (data not shown).

\section{DISCUSSION}

The percentages of ESBL production in our hospital was highly variable whether all methods were compared in an equal hierarchy. The data obtained using NCCLS breakpoints (KB method) provided rates of ESBL production much higher $(\mathrm{p}<0.005)$ than those obtained by other methods. However, one should consider that the KB method, as proposed by NCCLS (19), has to be use only as a screening method and therefore cannot be directly compared to the confirmatory methods. As a matter of fact, none aztreonam non-resistant and ceftriaxone

Figure 1. Macrorestriction analysis of DNA by pulsed-field gel electrophoresis of 15 isolates of ESBL $K$. pneumoniae $(\lambda=$ molecular weight marker of $48.5 \mathrm{~kb}$ ).

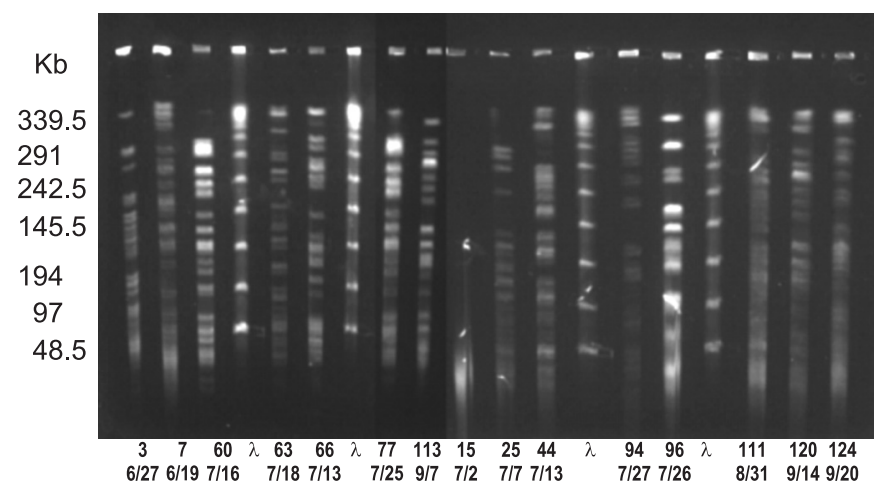


non-resistant isolates were ESBL-producers. This indicates that NCCLS breakpoints were not necessary to detect ESBL using these disks, as it gave only false-positive results in our population. In the case of the ceftazidime disks we could reduce de NCCLS breakpoints by $2 \mathrm{~mm}$ and we would have detected all ESBL-producers. We, therefore, agree with Lee et al. (11) that adjusting breakpoints to detect ESBL in different countries or regions is important to avoid false-positive results and unnecessary work. In view of that, we will consider only the methods of DD, MIC CAZ/CAC and MIC CAZ to indicate the real rates of ESBL production in this study. The CAZ/CAC method also showed similar rates for ESBL although it was not used for all isolates tested by the other three methods.

The prevalence of $K$. pneumoniae around the world varies greatly although it tends to be less than $25 \%$ in many countries $(1,3,13,16,24)$. We, therefore, considered that the prevalence of ESBL was quite high among isolates of $K$. pneumoniae in this study.

The difference, although not statistically significant, in range among the confirmatory methods could be attributed mainly to the fact that the methods are based in different characteristics of the enzyme. Thus, while the DD and MIC CAZ/CAC methods evaluate inhibition of the $\beta$-lactamase enzyme by clavulanic acid, the method of MIC CAZ take in account the raise of resistance. The latter determination is less specific for ESBL production since it may detect resistance due to other mechanisms such as AmpC production (1). Data obtained in this study for Klebsiella spp corroborated that MIC CAZ is less specific for ESBL production. It has also to be considered that in some occasions the inhibitory effect of clavulanic acid was not clearly visualized in the DD method (5). Therefore, the interpretation of results in this method was somehow empiric and may depend on individual basis as there is no standard interpretative criteria which may difficult the use of this method in the routine laboratories. Another problem of this method, the distance between disks (1), can be illustrated by isolate number 15 which would be considered negative for ESBL production using DD method with disks $1.5 \mathrm{~cm}$ apart. This isolate was retested changing only the distance between disks (reduced to $1.0 \mathrm{~cm}$ ) and this resulted in a clear inhibitory effect of the clavulanic acid which was barely seen before (Fig. 2).

To estimate the existence of an outbreak of ESBL $K$. pneumoniae we performed macrorestriction analysis of DNA by pulsed-field gel electrophoresis. The data obtained indicated that the isolates had no clonal relation as each patient was harboring a distinct strain. Thus, the high prevalence of ESBL Klebsiella in our hospital is probably consequence of individual selection of resistant strains rather than due to the transmission of a common strain between patients. This diversity in genotype was also described in Taiwan by Liu et al. (30) who suggested that the increase of ESBL $K$. pneumoniae in their hospital was mainly due to dissemination, or mutation, in plasmids containing
Figure 2. Effect of the distance between disks using the doubledisk diffusion method.

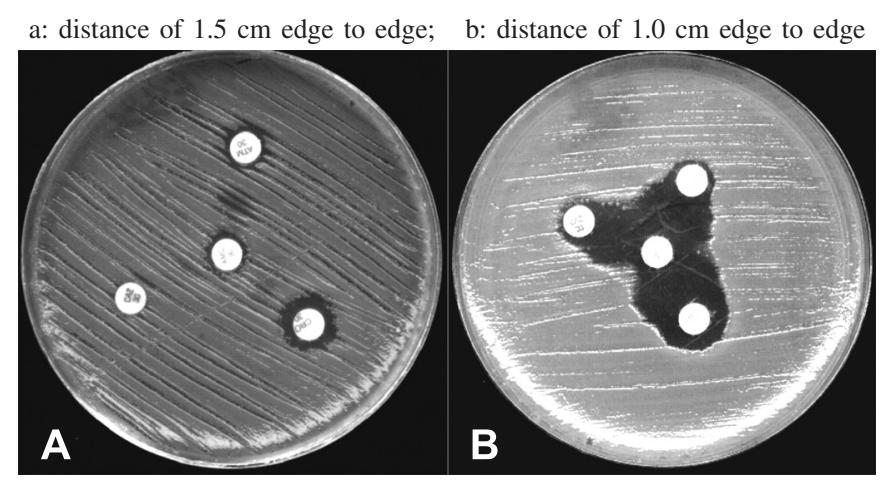

resistant genes. Conversely, in other centers the increase of ESBL K. pneumoniae was correlated with a single, or few, clones $(17,30)$.

The high levels of ESBL, mainly among isolates of $K$. pneumoniae, in our hospital is worrying and warrants special attention by both the clinician and the microbiology laboratory. While the former has to re-evaluate the antibiotic policies, the laboratory must to be capable to readily identify these isolates.

\section{RESUMO}

\section{$\boldsymbol{\beta}$-lactamases de espectro ampliado em Klebsiella spp e em Escherichia coli obtidas em um hospital escola brasileiro: detecção, prevalência e tipagem molecular}

Este estudo foi desenvolvido para comparar métodos de detecção e para estimar a prevalência de Klebsiella spp e E.coli produtoras de $\beta$-lactamases de espetro ampliado (ESBL) em um Hospital Universitário no sul do Brasil. A correlação genética, determinada através de método molecular de tipagem, entre as amostras de K. pneumoniae também foi determinada. A produção de ESBL foi investigada em 95 amostras de Klebsiella spp e E.coli obtidas de pacientes no Hospital de Clínicas de Porto Alegre usando-se: medida do diâmetro a zona de inibição (KB), dupladifusão de disco (DD), valores de concentração inibitória mínima da ceftazidima (MIC CAZ), aumento do diâmetro da zona de inibição com adição de clavulanato (CAZ/CAC) e a relação entre o MIC da ceftazidima/MIC ceftazidima com clavulanato (MICCAZ/ CAC). A tipagem molecular foi realizada utilizando-se o método de macrorestrição de DNA e eletroforese em campo pulsado (PFGE). O método KB apresentou as maiores taxas de produção de ESBL (> 70\% para Klebsiella e 59\% para E.coli) contrastando com os outros métodos $(\mathrm{p}<0,05)$. Os métodos confirmatórios (DD, MIC CAZe MIC CAZ/CAC) indicaram a produção de ESBL em 8 a $13 \%$ de E.coli e em 33 a $40 \%$ para as espécies de Klebsiella. Portanto, o método KB é útil apenas como método de triagem devido aos diversos resultados considerados falso-positivos. A 
tipagem molecular realizada em 17 amostras de K.pneumoniae ESBL indicou não existência de relação clonal. Este estudo encontrou uma boa correlação entre os métodos confirmatórios de detecção de ESBL embora os métodos que avaliam a inibição da enzima pelo clavulanato pareçam ser mais específicos. A alta prevalência de Klebsiella ESBL em nosso hospital provavelmente se deve a seleção individual de cepas resistentes do que a transmissão de uma cepa comum.

Palavras-Chave: ESBL, Klebsiella, resistência, tipagem molecular.

\section{REFERENCES}

1. Bradford, P.A. Extended-spectrum $\beta$-lactamases in the $21^{\text {st }}$ century: characterization, epidemiology, and detection of this important resistance threat. Clin. Microbiol. Rev., 14:933-951, 2001.

2. Bush, K.; Jacoby, G.A.; Medeiros, A.A. A functional classification for $\beta$-lactamases and its correlation with molecular structure. Atimicrob. Agents Chemother., 39:1211-1233, 1995.

3. Cormican, M.G.; Marshall, A.S.; Jones, R. Detection of extendedspectrum beta-lactamase (ESBL)-producing strains by Etest ESBL screen. J. Clin. Microbiol., 34:1880-1884, 1996.

4. Cotton, M.F.; Wasserman, E.; Pieper, C.H.; Theron, D.C.; vanTubberght, D.; Campbell, G.; Fangs, F.C.; Barnes, J. Invasive disease due to extended spectrum $\beta$-lactamase-producing Klebsiella pneumoniae in a neonatal unit: the possible role of cockroaches. $J$. Hospital Infect., 44:13-17, 2000.

5. Coudron, P.E.; Moland, E.S.; Sanders, C.C. Occurrence and detection of extended-spectrum $\beta$-lactamases in members of the family Enterobacteriaceae at a veterans medical center: seek and you may find. J. Clin. Microbiol., 35:2593-2597, 1997.

6. Emory, C.L.; Weymouth, L.A. Detection and clinical significance of extended-spectrum $\beta$-lactamases in a tertiary-care medical center. J. Clin. Microbiol., 35:2061-2067, 1997.

7. Gales, A.C.; Sader, H.S.; Machado, A.M.O.; Jones, R.N.; Pignatari, A.C. Comparação das atividades antimicrobianas da cefepima e ceftazidima em 1015 amostras bacterianas isoladas no Hospital São Paulo. J. Bras. Patol., 31:55-60, 1995.

8. Jacoby, G.A. Extended- spectrum $\beta$-lactamases and other enzymes providing resistance to oxymino $\beta$-lactams. Infect. Dis. Clin. N. Amer., 11:875-887, 1997.

9. Jacoby, G.A.; Medeiros, A.A. More extended-spectrum $\beta$-lactamases. Antimicrob. Agents Chemother, 35:1697-1704, 1991.

10. Kaufmann, M.E. Pulsed-field gel electrophoresis. In: Woddford N, Johnson AP. Molecular Bacteriology: Protocols \& clinical application. Humana Press, New Jersey, 1998, p.33-50.

11. Lee, K.; Lim, J.K.; Yong, D.; Yum, J.; Chong, Y.; Okamoto, R.; Inoue, M. Evaluation of efficiency of screening extended-spectrum $\beta$-lactamases-producing Escherichia coli and Klebsiella pneumoniae in Hospitals where the bacteria are increasingly prevalent. J. Clin. Microbiol., 39:3696-3699, 2001.

12. Liu, P.Y.; Tung, J.C.; Ke, S.C.; Chen, S.L. Molecular epidemiology of extended-spectrum $\beta$-lactamase-producing Klebsiella pneumoniae isolates in a district hospital in Taiwan. J. Clin. Microbiol., 36:27592762, 1998.

13. Livermore, D.M.; Winstanley, T.G.; Shannon, K.P. Interpretative reading: recognizing the unusual end inferring resistance mechanisms from resistance phenotypes. J. Antimicrob. Chemother, 48:87-102, 2001.

14. Livermore, D.M.; Yuan, M. Antibiotic resistance and production of extended-spectrum $\beta$-lactamases amongst Klebsiella spp. from intensive care units in Europe. J. Antimicrob. Chemother., 38:409-424, 1996.
15. Lucet, J.C.; Chevret, S.; Decré, D.; Vanjak, D.; Macres, A.; Bédos, J.P.; Wolff, M.; Regnier, B. Outbreak of multiply resistant Enterobacteriaceae in an intensive care unit: epidemiology and risks for acquisition. Clin, Infect. Dis., 22:430-436, 1996.

16. Lyon, D.J.; Scheel O.; Adeyemi-Doro, F.A.; Ling, T.K.; Cheng, A.F.; Norby, S.R. Antimicrobial susceptibility and extended-spectrum betalactamases of Hong Kong isolates of Enterobacteriaceae. Scand. J. Infect. Dis., 101:17-20, 1996.

17. Mangeney, N.; Niel, P.; Faubert, P.G.; Hue, S.; Dupeyron, C.; Louarn, F.; Leluan, G. A 5-year epidemiological study of extended-spectrum $\beta$ lactamase producing Klebsiella pneumoniae isolates in a medium and long-stay neurological unit. J. App. Microbiol., 88:504-511, 2000.

18. Meyer, K.S.; Urban, C.; Ergan, J.; Berger, B.J.; Rahal, J.J. Nosocomial outbreak of $K$. pneumoniae infection resistant to late-generation cephalosporins Ann. Intern. Med., 119:353-358, 1993.

19. National Committee for Clinical Laboratory Standards. 1998. Approved Standard M2-A6. National Committee for Clinical Laboratory Standards, Wayne, Pa.

20. National Committee for Clinical Laboratory Standards. 2001. Approved Standard M100-S11. National Committee for Clinical Laboratory Standards, Wayne, Pa.

21. Naumovski, L.; Quinn, J.P.; Miyashiro, D.; Patel, M.; Bush, K.; Singer, S.; Graves, D.; Palzkill, T.; Arvin, A.M. Outbreak of ceftazidime resistance due to novel extended-spectrum $\beta$-lactamase in isolates from cancer patients. Antimicrob. Agents Chemother., 36:1991-1996, 1992.

22. Nuesch, M.T.; Hachler, H.; Kayser, F.H. Detection of genes coding for extended-spectrum SHV $\beta$-lactamases in clinical isolates by a molecular genetic method, and comparison with the Etest. Eur. J. Clin. Microbiol. Infect. Dis., 15:398-402, 1996.

23. Pena, C.; Pujol, M.; Ardanuy, C.; Ricart, A.; Pallares, R.; Ariza, J.; Gudiol, F. Epidemiology and successful control of a large outbreak due to Klebsiella pneumoniae producing extended-spectrum $\beta$ lactamases. Antimicrob. Agents Chemother., 42:53-58, 1998.

24. Piddock, L.J.; Walters, R.N.; Jin, Y.F.; Turner, H.L.; Gascoyne, D.M.; Hawkey, P.M. Prevalence and mechanism of resistance to 'thirdgeneration' cephalosporins in clinically relevant isolates of Enterobacteriaceae from 43 hospitals in the UK, 1990-1991. J. Antimicrob. Chemother, 39:177-187, 1997.

25. Rice, L.B.; Willey, S.H.; Papanicolaou, G.A.; Medeiros, A.A.; Eliopoulos, G.M.; Moellering, R.C.; Jacoby, G.A. Outbreak of ceftazidime resistance caused by extended-spectrum $\beta$-lactamases at a Massachusetts chronic-care facility. Antimicrob. Agents Chemother., 34:2193-2199, 1990.

26. Sirot, D.L.; Goldstein, F.W.; Soussy, C.J. Resistance to cefotaxime and seven other $\beta$-lactams in members of the family Enterobacteriaceae: a 3-year survey in France. Antimicrob. Agents Chemother., 36:1677-1681, 1992.

27. Steward, C.D.; Rasheed, J.K.; Hubert, S.K.; Biddle, J.W.; Raney, P.M.; Anderson, G.J.; Williams, P.P.; Brittain, K.L.; Oliver, A.; MacGowan, J.E.; Tenover, F.C. Characterization of clinical isolates of Klebsiella pneumoniae from 19 laboratories using the National Committee for Clinical Laboratory standards extended-spectrum- $\beta$-lactamase detection methods. J. Clin. Microbiol., 39:2864-2872, 2001.

28. Tenover, F.C.; Arbeit, R.; Goering, R.; Mickelsen, P.; Murray, B.; Persing, D.; Swaminathan, B. Interpreting chromosomal DNA restriction patterns produced by pulsed-field gel electrophoresis: criteria for bacterial strain typing. J. Clin. Microbiol., 33:2233-2239, 1995.

29. Vercauteren, E.; Descheemaeker, P.; Leven, M.; Sanders, C.C.; Goossens, H. Comparison of screening methods for detection of extended-spectrum $\beta$-lactamases and their prevalence among blood isolates of Escherichia coli and Klebsiella spp. in a Belgiam teaching hospital. J. Clin. Microbiol., 35:2191-2197, 1997.

30. Weller, T.M.; MacKenzie, F.M.; Forbes, K.J. Molecular epidemiology of a large outbreak of multiresistant Klebsiella pneumoniae. J. Med. Microbiol., 46:921-926, 1997. 